\title{
Bioethics and the Freedom Road. The JBI Community and the Change We Want To See
}

\author{
Michael A. Ashby • Bronwen Morrell
}

Published online: 2 July 2018

(C) Journal of Bioethical Inquiry Pty Ltd. 2018

Keywords Freedom · Liberty - Imagination · Dialogue . Individualism $\cdot$ Autonomy

The most fundamental issue in politics, and ethics, is that of individual liberty weighed against the interest of others, of the collective, and there is clearly a global crisis of lonely individualism and numerous examinations of the nature of social solidarity in our times (see, for example, Lost Connections, Hari 2018). How do we work with this tension and find some sort of balance?

Bioethics is in its essence a collaborative dialogue, an international conversation about matters where there is no universally agreed way to proceed, where difference is explored, but even fundamental rights and principles are contested. The best way to do this is in a spirit of multidisciplinary and diverse-perspective curiosity. If we adopt the idea attributed to Gandhi, to "be the change you want to see in the world" (not his exact words apparently, and

\footnotetext{
M. A. Ashby $(\bowtie)$

Palliative Care Service, Royal Hobart Hospital, Tasmanian Health Service, and School of Medicine, Faculty of Health Sciences, University of Tasmania, 1st Floor, Peacock Building, Repatriation Centre, 90 Davey Street, Hobart, TAS 7000, Australia

e-mail: michael.ashby@ths.tas.gov.au

B. Morrell

Faculty of Medicine and Health, The University of Sydney, Sydney Health Ethics, Level 1, Medical Foundation Building, K25, University of Sydney, NSW 2006, Australia e-mail: bronwenmorrell@gmail.com
}

he was talking of inner self transformation changing the world, see Ranseth 2015), the Journal of Bioethical Inquiry seeks to link people in a way that mirrors the mission of the journal and its communitarian aspirations.

Many years ago, at the beginning of his palliative care career in Australia, one of us (MA) was a medical director at Calvary Hospital in Adelaide, South Australia. He asked the Sister Administrator why they were called the Little Company of Mary (LCM). It was explained that the Little Company consisted of the nuns, but the Greater Company was everybody outside the religious order who worked with them in order to discharge their mission. The JBI board and editorial team sees a journal as a virtual community, and perhaps the LCM is a good conceptual model for this community, centred around the production of the journal but also inclusive of everyone who has a contribution to make. Whether you are an author, peer reviewer, or one of our associate editors, you are a valued member of this community and we welcome your input and ideas. The JBI is a small part of a global conversation to promote insights and new perspectives about the conduct of the life sciences and healthcare. We inhabit an everchanging world of publishing a media, and the board is constantly looking at how best to position the journal and its community in this global business milieu. We are keen to ensure that we have the correct balance of academic experience together with meeting the publication needs of young developing scholars. There is, however, no desire in our leadership group to feed the "publish or perish" mentality of the international 
university scene. It is hard for academics and researchers at all stages of career to retain morale and good humour in an environment in which the metrics of publication record and grant seeking drive everything - including huge amounts of transmitted stress and anxiety. We very much heed long heard warnings about the corrosive effects of the dangers of poor quality research being published with the sole purpose of survival and progression of careers (see for example Altman 1994). It is also both depressing and silly to hear that a recent estimate of university faculty time in the United States shows that academic staff spends over half the time writing grant applications that fail (see Smith 2018)! So our emphasis will remain on the production and dissemination of articles that reflect our brand contribution to global bioethics. The values we espouse in this are centred on notions of multidisciplinary and multi-method inquiry, in-depth scholarship, and both scientific and philosophical rigour.

We are always on the lookout for new people and new ideas to join our community. In particular, we are interested in hearing from anyone who feels that they might wish to join our group of Associate Editors in the key subject portfolio areas that the journal has so far identified-Clinical Ethics, Cross-Cultural Bioethics, Environmental and Non-Human Animal Ethics, Ethics and Faith, Ethics and Reproduction, Globalization, Law, Mental Health, Nursing Ethics, Public Bioethics, Queer Theory and Disability Studies, Research Ethics, Science and Genetics, and Women and Children Bioethics.

Over the next few months we will be mapping out our programme for themed issues and symposia for forthcoming volumes. Over the last fourteen years we have published a wide range of symposia and special issues brought together by guest editors from a range of philosophical and disciplinary perspectives including: Directto-consumer advertising (Christopher Jordens and Lynley Anderson), Ethics and stem cell research (Lynette Reid, Josephine Johnston, and Françoise Baylis), The human body (Cameron Stewart), AsiaPacific bioethics (Ian Kerridge, Margaret SleeboomFaulkner, and Paul Komesaroff), Reconfiguring disability (Shelley Tremain), Nanotechnology (Alan Petersen), Infectious disease ethics (Michael J. Selgelid, Angela R. McLean, Nimalan Arinaminpathy, and Julian Savulescu), End of life (Ian Kerridge, Paul Komesaroff, Mal Parker, and Elizabeth Peter), Illuminating environmental ethics (Rob Irvine), Complementary and alternative medicine (Grant Gillett), Biopolitics (Catherine
Mills), Dignity (Claire Hooker), Neuroethics and mental health (Michael Robertson), Futility (Sarah Winch and Ian Kerridge), Reconciliation (Paul Komesaroff, Elizabeth Kath, and Paul James), Donation of stem cells and reproductive tissue (Catherine Waldby, Ian Kerridge, and Loane Skene), Bioethics, sexuality, and gender identity (Lance Wahlert and Autumn Fiester), Cases and culture, Public health ethics (Stacy M. Carter and Lucie Rychetnik), Food ethics (Rob Irvine), Moral distress (Elizabeth Peter), Nonhuman animal ethics (Rob Irvine, Chris Degeling, and Ian Kerridge), Bioethics and literature (Grant Gillett and Lynne Bowyer), Ethical dilemmas in prisoner care (Tenzin Wangmo, David M. Shaw, and Bernice S. Elger), Disease, communication, and the ethics of (in)visibility (Martha Stoddard Holmes and Monika PietrzakFranger), Global health and global health ethics (Catherine Myser), Bioethics and epistemic scientism (Christopher Mayes, Claire Hooker, and Ian Kerridge), Tuberculosis (Paul H. Mason and Chris Degeling), Structural competency (Helena Hansen and Jonathan Metzl), Composing disability (Abby Wilkerson, Joseph Fisher, and Wade Fletcher), and Public trust in expert knowledge (Silvia Camporesi, Maria Vaccarella, and Mark Davis).

There is no reason why we should not periodically revisit themes that have been covered in the past in our symposia, but we are certainly on the lookout for new topics and perspectives. If you feel that you have a special area that will benefit from coverage in a $J B I$ special issue and that you and your colleagues would be willing to curate a symposium, we would be very pleased to hear from you. We particularly encourage investigators in the postdoctoral phase of career to consider such a request, and we welcome expressions of interest at this level for Associate Editor positions.

In a world where fewer and fewer people pick up a big quarterly publication and read it from cover to cover, it is clear to us that the strength of the $J B I$, one of its defining features in the bioethics literature, is that it is a go to place for researchers and teachers on specific topics. Many of our readers these days may only visit us in order to access or download something specific to their area of research interest. We are pleased to be a resource for specific purposes but also hope that these visits or hits spark curiosity for the journal and that initial one-off visitors return regularly to see what is there! And it just may be these visits will foster an interest in joining the community. 
The board is actively considering a bigger emphasis on our symposia and special themed issues. We are keen that these reflect the thinking and research of younger investigators as well as senior established writers with international reputations. We are certainly more interested in innovation and inclusiveness than simply giving air time to those who have already climbed the steep and slippery ladder of academic career building in this era of managerial higher education.

We will also be looking at regular features on the key subject areas of bioethics, building on our successful legal "Recent Developments" feature edited by Bernadette Richards from Adelaide (and we certainly encourage more legal material in other manuscript categories as well). There will also be more opportunity for both commissioned and non-commissioned responses to our articles. If you wish to respond to one of our articles with a short paper of response rather than a letter, we are always pleased to consider this and to receive a short abstract prior to submission into the peer-reviewed editorial manager system.

We will keep you abreast of these developments through this editorial column and welcome your feedback and ideas. The bottom line is that whilst we will still welcome unsolicited articles, in the future it is likely that we will do more curation and invitation for themed material that strengthens the existing reputation, mission, image, and niche of the journal in this crowded global field. In all of this, we would not want to be exclusive, and for that reason we are very keen to expand $J B I$ as a community.

We are ever mindful of our global vision and the fact that we have the privilege of writing and editing in English as our first language. Despite the clear global nature of English in academic discourse, we know that most of the potential contributors do not have English as a first language and do an amazing job at communication of complex ideas in a language that is not their own. We also know that this is more than just a hegemony of language or style, it also has implications for culture, methodology, and worldview. In this issue we are certainly still nonetheless very western-centric, with authors from Australia (Haire et al. 2018; McWhirter and Eckstein 2018; Lenette et al. 2018; Prentice and Gillam 2018), Belgium (Vanderschaeghe et al. 2018), Germany (Hansen 2018), Switzerland (Wienand et al. 2018), Ireland (Emmerich and Gordjin 2018), the United Kingdom (Emmerich and Gordjin 2018), the United States (Nagy et al. 2018; Bailoor et al. 2018;
Yanke et al. 2018), and Singapore (arguably a bridge between "East" and "West" (Menon and Chuan 2018). Two articles are jurisdiction specific, to Australia (McWhirter and Eckstein 2018), and Nevada, USA (Yanke et al. 2018), but hopefully they act as exemplar case studies about issues of broader concern.

This issue of the $J B I$ is made up entirely of unsolicited articles and therefore there is no planned overarching theme of connection between any the contributions, embracing as they do five broad areas. In literature: the relationship between science fiction and bioethics (Hansen 2018) and the influence of the Frankenstein myth on public discourse (Nagy et al. 2018). In clinical ethics: disclosure of early biomarker diagnosis of Alzheimer's disease (Vanderschaeghe et al. 2018), moral equivalence of withholding and withdrawing treatment (Emmerich and Gordjin 2018), advance directives (Bailoor et al. 2018), and determination of brain death (Yanke et al. 2018). In research ethics: uptake of supplementary consent strategies (McWhirter and Eckstein 2018) and ethics approval of visual research methods (Lenette et al. 2018). In public health: use of coercive measures to encourage vaccination (Haire et al. 2018).

However, in one sense all the contributions have some relevance to the nature of freedom. Indeed much of western bioethics is concerned with the freedom of the individual, at its most simple and reduced level, it is a diverse and seemingly never-ending search for ways to ensure that the human rights of individuals are recognized and honoured. Clashes in worldview or action are nearly always resolved in favour of the individual, and social solidarity is on the back foot. This is the true nature of liberalism in the tradition of John Stuart Mill, but the challenge remains always to balance care and nurture of the individual with the more complex agenda of social liberalism (see Mark Pack from the Liberal Democrat History Group in the UK who has recently offered a philosophical history of liberalism on his blog website-https://www.markpack.org.uk).

Nowhere is this seen more starkly than in the area of vaccination. Fear of infectious diseases, particularly those that affect children, is managed by vaccination programmes that are enthusiastically promoted by governments. To dissent from this powerful alliance between government and its frightened citizens is to court government sponsored discrimination that has few parallels in modern democracies and almost inevitable stigmatization. This stand-off is examined in a piece of original research entitled "Raising Rates of Childhood 
Vaccination: The Trade-off Between Coercion and Trust" by Haire et al. (2018) from Australia. They examine many of the key concepts in bioethics: coercion by governments as part of public health policy, the nature of conscientious objection in this context, moral responsibility to vaccinate, the disinformation around vaccine safety and adverse events, alienation, loss of trust, equity, and efficacy. There is clearly a huge tension here between constructs of social good and herd immunity and the liberty/autonomy of individuals. The issue of freedom also arises in various ways in a number of other articles within this issue, whether it's hope and its role in freedom from despair (Wienand et al. 2018), the right to choose whether or not to receive results of biomarker-based testing for Alzheimer's disease (Vanderschaeghe et al. 2018), notions of relational autonomy in the context of biotechnologies and medicine (Hansen 2018), methods for facilitating autonomous decision-making (McWhirter and Eckstein 2018), barriers to enactment of autonomy in the form of advance care directives (Bailoor et al. 2018), moral distress as a result of the constraints imposed by shared decisionmaking (Prentice and Gillam 2018), the potential impact of Nevada's Uniform Determination of Death Act on informed consent and religious and cultural freedoms (Yanke et al. 2018), Menon and Huan in their Recent Developments contribution report a supreme court decision in Singapore that further shifts the emphasis of consent to medical treatment from a reasonable doctor to a reasonable patient standard. The case and its common law history show that freedom of the individual in health choices, informed consent and freedom of the individual to exercise well informed autonomous choices is a growing international standard and certainly a case of east meets west. A true and welcome global bioethical standard, and very much the sort of international conversation that this journal aspires to facilitate.

Philosophy Now (issue 117, 4-5) recently asked if metaphysics was dead, now that physics has explained so many of the questions that gave rise to it. Seemingly not if you look at no less than six of our articles in this issue that in various ways deal with human imagination in medical ethics: use of thought experiments as methodology (Emmerich and Gordjin 2018), the influence of the Frankenstein myth on public discourse (Nagy et al. 2018), the relationship between science fiction and bioethics (Hansen 2018), advance care plans and the imagined future self (Bailoor et al. 2018), imaginative arts based approaches to research and research translation such as digital storytelling and dance, especially for engaging with topics that are abstract or sensitive (Lenette et al. 2018), and hope and imagined possible futures (Wienand et al. 2018).

We hope you will join us in building our community, in which the group joins up to protect the individual, his/ her rights, aspirations, and dreamings. Buddhists see nothing as permanent and change as a constant. We hope this edition of the journal speaks to you and our project is one you might wish to share in. Please email us with any thoughts or ideas of your own.

\section{References}

Altman, D.G. 1994. The scandal of poor medical research. British Medical Journal 308: 283. https://doi.org/10.1136 /bmj.308.6924.283

Bailoor, K., L.H. Kamil, E. Goldman, L.M. Napiewocki, D. Winiarski, C.J. Vercler, and A.G. Shuman. 2018. The voice is as mighty as the pen: Integrating conversations into advance care planning. Journal of Bioethical Inquiry 15(2) https://doi.org/10.1007/s11673-018-9848-7

Emmerich, N., and B. Gordjin. 2018. A morally permissible moral mistake? Reinterpreting a thought experiment as proof of concept. Journal of Bioethical Inquiry 15(2): https://doi. org/10.1007/s11673-018-9845-x

Haire, B., P. Komesaroff, R. Leontini, and C.R. MacIntyre. 2018. Raising rates of childhood vaccination: The trade-off between coercion and trust. Journal of Bioethical Inquiry 15(2). https://doi.org/10.1007/s11673-018-9841-1

Hansen, S.L. 2018. Family resemblances: Human reproductive cloning as an example for reconsidering the mutual relationships between bioethics and science fiction. Journal of Bioethical Inquiry 15(2). https://doi.org/10.1007/s11673018-9842-0

Hari, J. 2018. Lost connections: Uncovering the real causes of depression-and the unexpected solutions. Bloomsbury Publishing.

Lenette, C., J.R. Botfield, K. Boydell, B. Haire, C.E. Newman, and A.B. Zwi. 2018. Beyond compliance checking: A situated approach to visual research ethics. Journal of Bioethical Inquiry 15(2). https://doi.org/10.1007/s11673-018-9850-0

McWhirter, R.E., and L. Eckstein. 2018. Moving forward on consent practices in Australia. Journal of Bioethical Inquiry 15(2). https://doi.org/10.1007/s11673-018-9843-Z

Nagy, P., R. Wylie, J. Eschrich, and E. Finn. 2018. The enduring influence of a dangerous narrative: How scientists can mitigate the Frankenstein myth. Journal of Bioethical Inquiry 15(2). https://doi.org/10.1007/s11673-018-9846-9

Prentice, T.M., and L. Gillam. 2018. Can the ethical best practice of shared decision-making lead to moral distress? Journal of Bioethical Inquiry 15(2). https://doi.org/10.1007/s11673018-9847-8 
Ranseth, J. 2015. Gandhi didn't actually ever say "Be the change you want to see in the world." Here's the real quote... [blog post]. Joseph Ranseth, August 27. https://josephranseth. com/gandhi-didnt-say-be-the-change-you-want-to-see-inthe-world/. Accessed June 13, 2018.

Smith, C. 2018. Higher education is drowning in BS. And it's mortally corrosive to society. The Chronicle of Higher Education, January 9. https://www.chronicle.com/article/Higher-EducationIs-Drowning/242195. Accessed June 13, 2018.

Vanderschaeghe, G., K. Dierickx, and R. Vandenberghe. 2018. Review of the ethical issues of a biomarker-based diagnoses in the early stage of Alzheimer's disease. Journal of Bioethical Inquiry 15(2). https://doi.org/10.1007/s11673018-9844-y
Wienand, I., M. Rakic, D. Shaw, and B. Elger. 2018. The beneficence of hope: Findings from a qualitative study with gout and diabetes patients. Journal of Bioethical Inquiry 15(2). https://doi.org/10.1007/s11673-018-9853-x

Yanke, G., M.Y. Rady, and J.L. Verheijde. 2018. Ethical and legal concerns with Nevada's brain death amendments. Journal of Bioethical Inquiry 15(2). https://doi.org/10.1007/s11673018-9852-y

Menon, S., and V.T. Chuan. 2018. Singapore modifies U.K. Montgomery test and changes the standard of care doctors owe to patients on medical advice. Journal of Bioethical Inquiry 15(2). https://doi.org/10.1007/s11673-018-9868-3 